\title{
Comparative Study of Pipeline Deliverables using Deterministic and Stochastic Models
}

\author{
Ernest O. Ihendeson, Awajiogak A. Ujile, and Anthony K. Leol
}

\begin{abstract}
This study aims to proffer solution to the factors causing delay is pipeline construction project deliverables, it compared deterministic model (variable with certainty) and stochastic model (variable with uncertainty), with Six (6) planned project schedules of Brownfield Energy Service Limited for pipeline construction. Time assigned to critical activities, identified from a network analysis, with the aid of the Critical Path Method, expected mean time, both deterministic and stochastic duration was calculated. Program Evaluation Review Techniques (PERT), the variance and standard deviation of the critical activities were also calculated. The probability of completion of a project within a given period was gotten with PERT. Comparing the results for deterministic duration 60 days to 79 days, which is $50 \%$ compared to $64 \%$. It was concluded that stochastic model is preferable when scheduling and executing pipeline construction projects, because uncertainties are factored into the planning and scheduling process including delays. Delays during execution stage, occurs mainly due to community related issues, equipment failures, change in job scope and work- men antics but not limited to these. This study advocates elimination of causes of delay, especially before and during project execution phase. It also suggested that every project schedule should follow an order of precedents, prerequisite, and management involvement and cooperation at all stages of the project.
\end{abstract}

Index Terms-Pipeline Construction; Project Deliverable; Deterministic Models; Stochastic Models; Project Scheduling; Project Planning; Project Duration.

\section{INTRODUCTION}

Pipeline construction project are projects which include, excavation of ditches, fitting, fabrication and welding activities. It also involves the use of heavy duty equipment such as swamp buggy (for swamp work), excavator (land work) different types of barges, York barge, lay barge, material barge, tugboats, and cranes etc. The length depends upon which purpose, it could be a trunk line; often very long from hundreds to thousands of kilometres, while delivery line and flow-lines run from metres to tenths of kilometres. Sometimes it cuts across different communities, villages, towns, cities and states. The length, size and the thickness (pipe thickness) of the pipeline are some of the things to consider when determining the project deliverables and time of completion (duration). Others include weather, terrains, personnel, equipment and management. Pipeline and flowlines are used basically for transportation of crude products from one point to another.

Everett \& Ronald [2], says Project is a one-time-only set of activities that has a definite beginning and ending point in

Published on January 31, 2019.

Authors are with Rivers State University, Port Harcourt, Nigeria. time. Project planning can be described as an outline of activities that establish a course of action for a project. Project scheduling can also be described as an outline of activities that establish the times and the sequence of project tasks. Activity is said to be a task within the project that has a definite beginning and ending date or point in time. The activity consumes time. For every project to succeed, it has to be planned, it activities outlined and scheduled.

Deliverables is an outcome that a project team must produce and present to the customer in accordance with the terms of a contract for a project to be complete. A deliverable can be tangible item such as a report, or an intangible item, such as performance of construction equipment. Every project has to produce something. If there are no deliverables there is no project, so says Roseke [7]. Pipeline construction project deliverables; include all the activities, ranging from project initiation, project design, project execution to project completion.

\section{A. Statement of the Problem}

In Nigeria most pipeline construction projects deliverables are not often completed on schedule. Delays often hamper project progress. Francois [3], listed factors causing delays to include:

i. Design error.

ii. Change of scope, "meanwhile the scope, define the entire deliverable that is expected at the end of the project".

iii. Inappropriate, inadequate procurement and faulty contractual management system.

iv. The complexity of the project is also a contributing factor to project delays. Complexity could be defined in terms of size of the project, most mega project with long schedule time could be affected by inflation, change in material price and exchange rate such that the initial budget may need to be supplemented for the project to be completed.

v. Community related issues, such as stop work order

\section{B. Aim and Objectives of Project}

The aim of this study is to proffer solution to the factors causing delay in pipeline construction project deliverables.

The objectives are as follows:

i. To analyse pipeline construction project deliverable using deterministic model

ii. To analyse pipeline construction project deliverable using stochastic model.

iii. To compare deterministic and stochastic models

iv. To Analyse how the models can help ensure smooth achievement of project deliverable

v. To determine which model to use in achieving pipeline construction deliverable target. 


\section{The Scope of Work}

i. Involves construction of flow line from well head to flow station

ii. Replacement of damage section of flow line

iii. Six (6) well heads were considered.

iv. Size of pipe for the flow line considered were 4" Schedule 80

\section{Significance of Study}

This study will help project team decide which model is the Optimum choice of project scheduling for project managers, project engineers and other professionals in Pipeline Construction industries.

\section{E. Extent of Past Works}

Gabriel [4], in his study stated that the unexpected events which cause construction project (deliverable) delay can be minimised by mindfulness, which is defined by five cognitive processes, namely: preoccupation with failure, reluctance to simplify, sensitivity to operations, commitment to resilience and deference to expertise. In Khan [6] research, it identified the factors contributing to construction project delays, it also analysed these factors and ranked them and then studied these factors and made recommendations on improving the overall project management methods, and to carefully formulated contract processes, with emphasis on the scope finalization, procurement planning, availability of skilled labour etc. While in Ograbee et.al [9], Last planner system he listed five levels of planning, Master schedule, phase schedule, look-ahead schedule, weekly schedule and percentage plan completed. When these five levels are implemented in a project it enhances planning processes, improves site logistics, and removes constraints before they become obstacles.

Rama et al [10], in their paper stated that project planning and scheduling is one of the most important aspect in construction project. It helps to estimate time and he used network analyses, deterministic model (CPM) and Stochastic model (PERT) to optimize time and resources. In his paper he used Deterministic and probabilistic technique and started that the project duration and cost were optimized. He further stated that project initial duration can be reducing by applying these techniques. He stated that CPM (Deterministic model) and PERT (Stochastic model) techniques are useful for the optimizing time schedule of any construction project, but that the complexity of this model increases when more activities are considered and their precedence relationship is complicated

Briggs [1], asked three questions in his research which are:

i. Why use a range of likely values in PERT?

ii. Does a single-point estimate produce a reasonable estimate of duration?

iii. Can a project manager determine how likely it is that the required duration can be met?

His answer to the first question was that range of value was used because of uncertainty of nature. For the second question his answer was yes, it does. While his answer for his third question was also yes, project managers can determine likely duration for any project. He also addressed the how both deterministic model and stochastic model time estimation techniques can be used to estimate time for the same project.

Iulian [5], investigated how uncertainty in duration for construction project and how the performance of construction project is affected by different degrees of uncertainty. He compared the deterministic analysis of a project schedule to stochastic analysis, how they differ and whether the optimal schedule of a project will be different from that produced using a deterministic analysis. He analysed the results for deterministic approach against the results from stochastic approach and stated that uncertainty is a very important factor in construction project that as the extents of uncertainty increases, the expected project duration also increases, that the optimum schedule in meeting the project objectives is not the deterministic project duration. He used artificial uncertainty because no data was available from his data source but concluded that project managers will be able to achieve optimum project duration for any given construction project using a stochastic linear schedule.

The current work is comparative one that will compare, using both deterministic and stochastic models to compute different pipeline projects deliverables, analyse, present their results and from these results state the preferred model. This research will attempt to bridge the gap from other literature whose values for the single point time estimate and three-point time estimate were simulated data was used.

\section{F. Significant of Using PERTT/CPM}

A Network diagram helps to translate complex project into a set of simple and logical arranged activities, according to Sharma [11] and therefore.

i. Helps in the clarity of thought and actions.

ii. Helps in clear and unambiguous communication developing from top to bottom vice versa among the people responsible for execution the project.

iii. Isolate activities that control the project completion and therefore, result in expeditious completion of the project.

iv. Helps in the division of responsibilities and therefore, enhance effective coordination among different departments/agencies involved

v. Helps in timely allocation of resources to various activities in order to achieve optima utilization of resources.

\section{MATERIALS}

The study area was on pipeline and flow-line construction projects schedules of a Company 'Brownfield Energy Services Limited'. The project schedules included four (4) pipeline and flow line construction project schedules and two (2) sectional replacement schedules. The project periods were from 2015 to 2017. These planned Project schedules from Brownfield Energy Services Limited were used as references documents. See TABLE I for a project schedule sample. 
TABLE I: TyPICAL PRECEDENCE TABLE WITH CPM TIME ESTIMATES

\begin{tabular}{|c|c|c|c|}
\hline $\mathrm{S} / \mathrm{n}$ & Activity & Immediate Predecessor & Activity Duration \\
\hline & A & & 3 \\
\hline & B & A & 5 \\
\hline & $\mathrm{C}$ & B & 4 \\
\hline & $\mathrm{D}$ & $\mathrm{C}$ & 5 \\
\hline & $\mathrm{E}$ & $\mathrm{D}$ & 2 \\
\hline & $\mathrm{F}$ & $\mathrm{C}, \mathrm{E}$ & 7 \\
\hline & $\mathrm{G}$ & $\mathrm{F}$ & 3 \\
\hline
\end{tabular}

TABLE II: PERT TIME ESTIMATE WITH EXPECTED MEAN TIME T $\mathrm{E}_{\mathrm{E}}$ AND VARIANCE

\begin{tabular}{llllll}
\hline \hline & & \multicolumn{3}{c}{ Expected mean time } \\
$\begin{array}{lllll}\text { Acti } \\
\text { vity }\end{array}$ & $\begin{array}{l}\text { Optimis } \\
\text { tic (a) }\end{array}$ & $\begin{array}{l}\text { Pessimis } \\
\text { tic (b) }\end{array}$ & $\begin{array}{l}\text { Most } \\
\text { Likely } \\
(\mathrm{m})\end{array}$ & $t=\frac{a+4 m+b}{6}$ & $\begin{array}{c}\text { Variance } \\
\sigma_{x}^{2}=\left(\frac{b-a}{6}\right)^{2}\end{array}$ \\
\hline A-B & 2 & 6 & 3 & 3.33 & 0.444 \\
B-C & 4 & 10 & 5 & 5.6 & 1 \\
C-D & 7 & 15 & 8 & & \\
D-E & 3 & 7 & 4 & & \\
E-F & 5 & 13 & 6 & & \\
F-I & 1 & 3 & 2 & & \\
I-J & 4 & 12 & 6 & & \\
J-K & 6 & 17 & 8 & & \\
K-L & 7 & 20 & 9 & & \\
\hline \hline
\end{tabular}

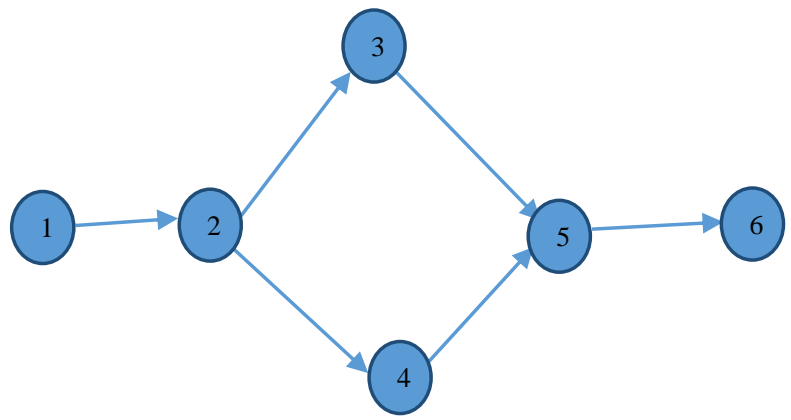

Fig. 1. A simple Network diagram

\section{Network Diagram}

A network diagram Show the sequence of all project activities. The sequences obey precedence requirement.

\section{METHODS}

\section{Identification of variables}

Deterministic model is a model with determined input and output variable while stochastic model are models where input and output are random variables (Activities). PERT (Program Evaluation and Review Techniques) and CPM (Critical Path Method) will be used to analyze the project schedules with the aid of Network models.

Critical path is defined as: The path whose activities are expected to consume the most time.

$\mathrm{Cpm}=\sum \mathrm{T}$ (summation of event time along critical path)

$$
\mathrm{CPM}=\mathrm{t}_{\mathrm{cp}}=\sum_{i=1}^{n} t_{c p}
$$

Where $t_{c p}$ is activity time along the critical path.

Expected mean time: $\mathrm{t}_{\mathrm{e}} \quad t=\frac{a+4 m+b}{6}$

Where $t_{\mathrm{e}}=$ Time estimate $\mathrm{t}_{\mathrm{o}}=\mathrm{a}=$ Optimistic time

$\mathrm{t}_{\mathrm{m}}=\mathrm{b}=$ most likely time

$\mathrm{t}_{\mathrm{p}}=\mathrm{c}=$ pessimistic time

According to Everett \& Ronald [2] all time are to be assigned based on experience or past data. The standard deviation and variance for the schedule, will be calculate, while the activities with certainty CPM, according to Martand [10] will represent the deterministic variable (model) and the probabilistic activities PERT (with uncertainty) will represent the stochastic variables (model).

$$
\begin{aligned}
& \text { Standard deviation }=\sqrt{\sigma}^{2}=\sigma=\frac{b-a}{6} \\
& \text { Variance }=\sigma^{2}=\sigma_{X}^{2}=\left(\frac{b-a}{6}\right)^{2}
\end{aligned}
$$

(Total Variance of the critical path).

It also states the expected duration (time) of the project. While PERT, Express the probability that the project is completed on schedule or within a specified period. Using

$$
\operatorname{PERT}=\mathrm{Z}=\frac{X-E}{\sigma}
$$

Where

$$
\begin{aligned}
& \mathrm{X}=\text { Due Date } \\
& \mathrm{E}=\text { Expected date of completion } \\
& \sigma=\text { Standard deviation }
\end{aligned}
$$

\section{RESULTS AND DISCUSSION}

\section{A. Deterministic Model: Calculating Project duration using $C P M$}

Data's from Appendices A to Appendices $\mathrm{F}$ and figure 1.

Critical path ( Table 3 , \& Figure 2 ) $=\mathrm{A}-\mathrm{B}+\mathrm{B}-\mathrm{C}+\mathrm{C}-$

$\mathrm{D}+\mathrm{D}-\mathrm{F}+\mathrm{F}-\mathrm{H}+\mathrm{H}-\mathrm{I}+\mathrm{I}-\mathrm{J}+\mathrm{J}-\mathrm{L}+\mathrm{L}-\mathrm{N}+\mathrm{N}-$

$\mathrm{O}+\mathrm{O}-\mathrm{P}+\mathrm{P}-\mathrm{Q}+\mathrm{Q}-\mathrm{R}$

$\mathrm{CPM}=2+2+3+4+16+2+3+4+4+3+2+2+2+7=60$ days.

See Table 7 for CPM of the Six schedules.

In the Network diagram above, there are 3 paths

Path 1: A - B - C - D- F - H- I - J - K - N - O - P - Q - R $=60$ days

Path 2: A - B - E - F - H - I - J - K - N - O - P - Q - R= 53 days

Path 3: A - B - F - G - H - I - J - K - N - O - P - Q - R= 53 days

Path 1 has 60 days which is the highest duration and is identified as the critical path and activities along it route as the critical activities. So the deterministic duration is 60 days.

\section{B. Calculating The Expected Mean Time, Variance And Standard Deviation}

Using the mathematical formulae below and data from Appendix G, H, I. J, K. L, M and N. Using (3):

$$
\mathrm{t}_{\mathrm{e}}=t=\frac{a+4 m+b}{6}
$$


From Appendix G

$\mathrm{t}_{\mathrm{e}}=t=\frac{2+4 * 3+7}{6}=\frac{9+12}{6}=\frac{21}{6}=3.5$

The duration of the project is obtained from the summation of critical activities time (expected of mean time). $\sum \mathrm{t}_{\mathrm{e}}=3.5+3.167+4+5.167+20+3.167+5.833+9.5+$ $1+4.667+3.333+3+1.5+2.667+8.667=79.167$ round up to 79 days.

See Appendix $\mathrm{G}$ to Appendix $\mathrm{N}$ for full results and TABLE IV for stochastic duration.

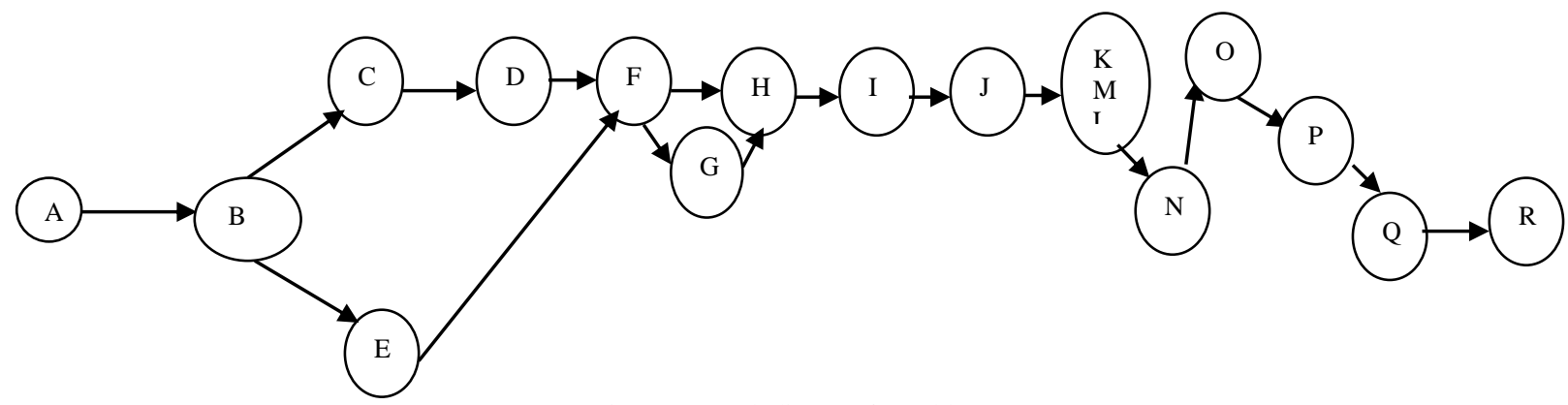

Fig. 2. Network diagram for Table 3

\begin{tabular}{|c|c|c|c|c|}
\hline & Activity & $\begin{array}{c}\text { Activity } \\
\text { Code }\end{array}$ & $\begin{array}{l}\text { Immediate } \\
\text { Predecessor }\end{array}$ & $\begin{array}{c}\text { Activity } \\
\text { Time }\end{array}$ \\
\hline $\bar{A}$ & Mobilization & $\mathrm{A}$ & & 2 \\
\hline B & Hse & & & 2 \\
\hline & Induction/Certification & $\mathrm{B}$ & A & \\
\hline $\mathrm{C}$ & Survey And Mapping & & & 3 \\
\hline & Out & $\mathrm{C}$ & B & \\
\hline $\mathrm{D}$ & Bush & & & 4 \\
\hline & Clearing/Excavation & $\mathrm{D}$ & $\mathrm{C}$ & \\
\hline $\mathrm{E}$ & Site Preparation & $\mathrm{E}$ & $\mathrm{B}$ & 2 \\
\hline $\mathrm{F}$ & Lay And Weld & $\mathrm{F}$ & $\mathrm{E}$ & 16 \\
\hline G & Ndt And Coating & $\mathrm{G}$ & $\mathrm{F}$ & 16 \\
\hline $\mathrm{H}$ & River Crossing & $\mathrm{H}$ & $\mathrm{F}, \mathrm{G}$ & 2 \\
\hline I & Pipe Alignment & I & $\mathrm{H}$ & 2 \\
\hline $\mathrm{J}$ & Tie In & $\mathrm{J}$ & I & 8 \\
\hline K & Flushing And Pipe & & & 1 \\
\hline & Filling & $\mathrm{K}$ & $\mathrm{J}$ & \\
\hline $\mathrm{L}$ & Pressure Testing & $\mathrm{L}$ & $\mathrm{K}$ & 3 \\
\hline M & Hook Up & M & $\mathrm{L}$ & 1 \\
\hline $\mathrm{N}$ & Back Filling & $\mathrm{N}$ & $\mathrm{L}$ & 3 \\
\hline $\mathrm{O}$ & Commissioning/Hand & & & 2 \\
\hline & Over & $\mathrm{O}$ & $\mathrm{M}, \mathrm{N}$ & \\
\hline $\mathrm{P}$ & Site Restoration & $\mathrm{P}$ & $\mathrm{O}$ & 2 \\
\hline Q & Demobilization & $\mathrm{O}$ & $P$ & 3 \\
\hline $\mathrm{R}$ & Close Out Report & $\mathrm{R}$ & Q & 7 \\
\hline
\end{tabular}

TABLE IV: STOCHASTIC MODEL DURATION

\begin{tabular}{lll}
\hline \hline Appendix & Stochastic Duration Days & \multicolumn{1}{c}{ Schedule/Project Title } \\
\hline Appendix G & 79 & 5LS \\
Appendix H & 74 & 01ANW \\
Appendix I & 52 & W8T \\
Appendix J & 67 & W24T \\
Appendix K & 70 & W9L \\
Appendix M & 66 & W18T \\
\hline \hline
\end{tabular}

$$
=\sigma_{X}^{2}=\left(\frac{7-2}{6}\right)^{2}=0.694
$$

Total variance is obtained from summation of variance along the critical activities

$$
\begin{aligned}
& \sum \sigma^{2}=0.694+0.250+0.111+0.250+1.778+0.250+ \\
& 1.361+0.694+0.000+1.000+0.111+0.111+0.028+ \\
& 0.111+1.000=7.76 \\
& \sum \sigma^{2}=7.76
\end{aligned}
$$

Standard deviation $=\sigma=\left(\frac{b-a}{6}\right)=\sqrt{7.76}=2.784$

$$
\sigma=2.784
$$

\begin{tabular}{llccc}
\multicolumn{5}{c}{ TABLE V: EXPECTED MEAN TIME, VARIANCE AND STANDARD DEVIATION. } \\
\hline \hline S/N & Project Titles & $\begin{array}{c}\text { Expected } \\
\text { mean time } \mathrm{t}_{\mathrm{e}}\end{array}$ & $\begin{array}{c}\text { Variance } \\
\sigma^{2}\end{array}$ & $\begin{array}{c}\text { Standard } \\
\text { Deviation } \sigma\end{array}$ \\
\hline 1 & 5LS & 79 & 7.751 & 2.784 \\
2 & 01ANW & 74 & 4.141 & 2.035 \\
3 & W8T & 52 & 3.419 & 1.849 \\
4 & W24T & 67 & 6.641 & 2.577 \\
5 & 9L & 70 & 3.251 & 1.803 \\
6 & W18T & 66 & 5.276 & 2.297 \\
\hline
\end{tabular}

\section{Calculating The Program Evaluation Review Technique.}

From TABLE V and TABLE VI and using equation 5 the PERT Z can be calculated.

$\mathrm{PERT}=\mathrm{Z}=\frac{X-E}{\sigma}$

These results satisfy the objective two of this research. Using (3) we calculate the variance

Variance $=\sigma^{2}=\sigma_{X}^{2}=\left(\frac{b-a}{6}\right)^{2}$

(Total Variance of the critical path activities).

Where

$\mathrm{Z}=$ Probability of completion at a given time (from normal distribution)

$\mathrm{X}=$ The probability variable

$\mathrm{E}=$ Expected date of completion from $\mathrm{t}_{\mathrm{e}}$

$\sigma=$ Standard deviation

PERT (Project evaluation and review techniques) will be base on three possibilities, finding probability of completing 
the job on schedule (at expected completion date) due date $\mathrm{E}$, and at 5days less than expected time $\mathrm{E}$ then the probability of completing the project between schedule date an expected time $\mathrm{X}$ and $\mathrm{E}$. in these cases at the expected time $E$ and five (5) days less.

The probability of completing the project $\mathrm{W} 5 \mathrm{~L} / \mathrm{S}$ at the 80days and day more than the estimated 79 is given by:

$$
\text { Probability } \quad Z_{80}=\frac{80-79}{2.784}=\frac{1}{2.784}=0.3590
$$

Where $\mathrm{E}=79, \mathrm{X}=80$ and standard deviation $=2.74$

$$
\mathrm{Z}_{80}=0.359 \text {. }
$$

Using normal distribution table on excel, we have

$$
\mathrm{Z}_{80}=0.640=64 \%
$$

This completes objective 3 .

The probability of completing the project $\mathrm{W} 5 \mathrm{~L} / \mathrm{S}$ at the 75 days is given by

Probability

$$
\begin{aligned}
& Z_{75}=\frac{75-79}{2.784}=-1.437 \\
& -1.437=0.075 \\
& Z_{75}=7.50 \%=8.0 \% \text { approx. }
\end{aligned}
$$

The probability of completing the project W5L/S between 75 and 80 days is given by

Probability

$$
\begin{aligned}
& Z_{80-75}=Z_{80}-Z_{75}=64-8=56 \% . \\
& Z_{80-75}=56 \% .
\end{aligned}
$$

TABLE VI: EXPECTED MEAN TIME, STANDARD DEVIATION

\begin{tabular}{llllll}
\hline \hline S/n & Tables & Duration $\left(\mathrm{t}_{\mathrm{e}}\right)$ & $\sigma$ & $\mathrm{X}$ & Remark \\
& & $\mathrm{E}$ & & & \\
\hline 1 & Appendix A & 79 & 2.784 & 75 & 5LS \\
2 & Appendix B & 74 & 2.035 & 70 & 01ANW \\
3 & Appendix & 52 & 1.849 & 48 & W8T \\
4 & Appendix & 67 & 2.577 & 63 & W24T \\
5 & Appendix & 70 & 1.803 & 66 & 9L \\
6 & Appendix & 66 & 2.297 & 62 & W18T \\
\hline \hline
\end{tabular}

\section{Comparing Deterministic Model Results And} Stochastic Model Result.

This section compares deterministic model to stochastic Model base on the schedule duration for the same project and same critical activities and paths. The difference is as a result of consideration for uncertainty, which allows for delay causing element to be treated without affecting set duration.

TABLE VII: Comparing Deterministic and Stochastic Duration

\begin{tabular}{lllll}
\hline \hline S/n & $\begin{array}{c}\text { Project } \\
\text { Title }\end{array}$ & $\begin{array}{c}\text { Deterministic } \\
\text { Duration (Days) }\end{array}$ & $\begin{array}{c}\text { Stochastic } \\
\text { Duration (Day) }\end{array}$ & $\begin{array}{c}\text { Difference } \\
\text { (Days) }\end{array}$ \\
\hline 1 & 5LS & 60 & 79 & 19 \\
2 & 01ANW & 39 & 74 & 35 \\
3 & W8T & 49 & 52 & 03 \\
4 & W24T & 56 & 67 & 12 \\
5 & W9L & 41 & 70 & 29 \\
6 & W18T & 51 & 66 & 15 \\
\hline \hline
\end{tabular}

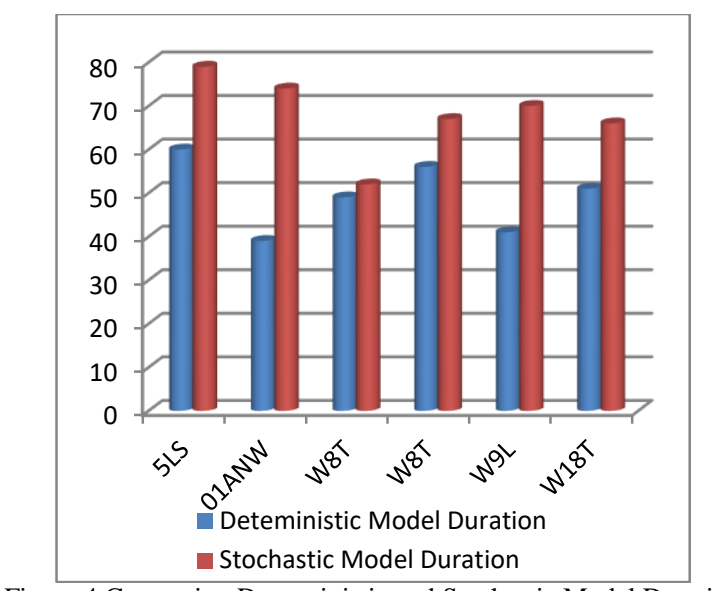

Figure 4 Comparing Deterministic and Stochastic Model Duration

\section{DISCUSSION}

Network diagram analysis was used to identify the critical path which is with the longest duration. This path outlined the critical activities, and these activities time (duration) were used to determine the values in table 7 which shows durations for both Deterministic and Stochastic Model time estimation for the Six (6) flowlines. With CPM, using onepoint time estimate, standard Deviation cannot be calculated therefore the probability of completing the project between a set time cannot be determined. With PERT, mean expected time, standard deviations, probability of completion were determined and shown on TABLE VI and Appendix D. The difference in duration between the Deterministic and stochastic Duration depends on the level of uncertainty, where the level of uncertainty is minimal the difference is also minimal example is the schedule of W18T where the difference is three days, compared to that of W9L 29 Days and 01ANW 35 Days as shown on TABLE VII.

The Deterministic and Stochastic durations result satisfies objectives 1 and 2 of the study. While the difference in their value for the same project, with the stochastic duration having more days because it considers uncertainty and uses a three-point time estimate, optimistic time which is the assigned time to each activity and regarded as the possible time required to complete the task. The pessimistic time regarded as the worst time to complete the task considering unknown uncertainty. Then the most likely time, which is next best time to complete the task should optimistic time fails.

Comparing the stochastic duration to the Deterministic duration, stochastic duration has more days but better chance of success because most uncertainty has being tackled. With better chance for success Stochastic Duration is preferred by deterministic model duration. This satisfies objective 5 and makes stochastic model scheduling the Optimum choice for project scheduling.

\section{CONCLUSION}

From the results and discussion, it was concluded that the optimum choice of model for pipeline construction project planning and execution is the stochastic model. That planning with stochastic model (for uncertainty) solves the problems of delay duration pipeline construction project. A 
pre-planned work procedure must be followed; any change in procedure has to be communicated to the CSR (Company Site Representative), members of the project team informed. When job scope changes, take time out and re-plan with CSR on the change or additional scope, evaluate how the changes affect the previous completion time E. Calculate the new $\mathrm{E}$ and inform the team about the changes. Always plan the task and activities following order of precedent and prerequisite. This study will serve to enlighten and advice project managers, engineers and project planners on which scheduling method and model to employ when planning for construction projects. They have to realize that the nature is stochastic and therefore the need to plan for uncertainty. Doing this will help each planning team to achieve the planned project deliverable target and within a scheduled duration. Both Deterministic and Stochastic Model are useful for project smooth delivery, but for optimum delivery this study recommends Stochastic Model because it treats uncertainty by using Average time.

\section{ACKNOWLEDGEMENT}

The Authors wish to thank Dr B. Nkoi for his supervising role, and the Department of Mechanical Engineering, Rivers State University, Nkpolu, Port Harcourt for providing an enabling environment for this research to be conducted.

\section{APPENDICES}

APPENDIX A: PROJECT SCHEDULE FOR WELL 5L/S CONSTRUCTION

\begin{tabular}{|c|c|c|c|c|}
\hline $\mathbf{S} / \mathbf{n}$ & Activities Description & Start Date & End Date & Duration (Days) \\
\hline 1 & Mobilization & $25 / 10 / 2015$ & $26 / 10 / 2015$ & 2 \\
\hline 2 & Hse Induction/Certification & $26 / 10 / 2015$ & $27 / 10 / 2015$ & 2 \\
\hline 3 & Survey And Mapping Out & $27 / 10 / 2015$ & $29 / 10 / 2015$ & 3 \\
\hline 4 & Bush Clearing/Excavation & $28 / 10 / 2015$ & $31 / 10 / 2015$ & 4 \\
\hline 5 & Site Preparation & $30 / 10 / 2015$ & $31 / 10 / 2015$ & 2 \\
\hline 6 & Lay And Weld & $01 / 11 / 2015$ & $15 / 11 / 2015$ & 16 \\
\hline 7 & Ndt And coating & $01 / 11 / 2015$ & $15 / 11 / 2015$ & 16 \\
\hline 8 & River Crossing & $16 / 11 / 2015$ & $17 / 11 / 2015$ & 2 \\
\hline 9 & Pipe Alignment & $17 / 11 / 2015$ & $18 / 11 / 2015$ & 2 \\
\hline 10 & Tie In & $19 / 11 / 2015$ & $27 / 11 / 2015$ & 8 \\
\hline 11 & Flushing And Pipe Filling & $27 / 11 / 2015$ & $27 / 11 / 2015$ & 1 \\
\hline 12 & Pressure Testing & $27 / 11 / 2015$ & $29 / 11 / 2015$ & 3 \\
\hline 13 & Hook Up & $29 / 11 / 2015$ & $29 / 11 / 2015$ & 1 \\
\hline 14 & Back Filling & $29 / 11 / 2015$ & $01 / 12 / 2015$ & 3 \\
\hline 15 & Commissioning/Hand Over & $01 / 12 / 2015$ & $02 / 12 / 2015$ & 2 \\
\hline 16 & Site Restoration & $02 / 12 / 2015$ & $03 / 12 / 2015$ & 2 \\
\hline 17 & Demobilization & $03 / 12 / 2015$ & $05 / 12 / 2015$ & 3 \\
\hline 18 & Close Out Report & $06 / 12 / 2015$ & $12 / 12 / 2015$ & 7 \\
\hline
\end{tabular}

APPENDIX B: SECTIONAL REPLACEMENT W8T/INSTALLATION OF PLATFORM (W8T/W2T)

\begin{tabular}{|c|c|c|c|c|}
\hline $\mathbf{S} / \mathbf{n}$ & Activities Description & Start Date & End Date & Duration (Days) \\
\hline 1 & Mobilization & $05 / 05 / 2017$ & $06 / 05 / 2017$ & 2 \\
\hline 2 & Hse Induction/Documentation & $06 / 05 / 2017$ & $06 / 05 / 2017$ & 1 \\
\hline 3 & Pressurizations Of Wells 8. & $07 / 05 / 2017$ & $08 / 05 / 2017$ & 2 \\
\hline 4 & Fabrication Of Platform W8t & $07 / 05 / 2017$ & $13 / 05 / 2017$ & 7 \\
\hline 5 & Leak Line Tracing & $06 / 05 / 2017$ & $08 / 05 / 2017$ & 3 \\
\hline 6 & Unbolting At Wellhead & $08 / 05 / 2017$ & $08 / 05 / 2017$ & 1 \\
\hline 7 & Unbolting At Flow Station & $09 / 05 / 2017$ & $09 / 05 / 2017$ & 1 \\
\hline 8 & Flushing And Cutting Of Line & $09 / 05 / 2017$ & $09 / 05 / 2017$ & 1 \\
\hline 9 & Fabrication Of Platform W2t & $12 / 05 / 2017$ & $18 / 05 / 2017$ & 7 \\
\hline 10 & Lay And Well & $10 / 05 / 2017$ & $13 / 05 / 2017$ & 4 \\
\hline 11 & River Crossing & $14 / 05 / 2017$ & $14 / 05 / 2017$ & 1 \\
\hline 12 & Cleaning /Brushing Platforms & $12 / 05 / 2017$ & $17 / 05 / 2017$ & 3 \\
\hline 13 & Tie In & $13 / 05 / 2017$ & $14 / 05 / 2017$ & 2 \\
\hline 14 & Flushing And Filling Of Line & $14 / 05 / 2017$ & $14 / 05 / 2017$ & 1 \\
\hline 15 & Hydro Test/pressure testing & $14 / 05 / 2017$ & $15 / 05 / 2017$ & 2 \\
\hline 16 & Depressurization & $15 / 05 / 2017$ & $15 / 05 / 2017$ & 1 \\
\hline 17 & Hook Up & $15 / 05 / 2017$ & $15 / 05 / 2017$ & 1 \\
\hline 18 & Backfilling Of Lines & $15 / 05 / 2017$ & $16 / 05 / 2017$ & 2 \\
\hline 19 & Commissioning, Hand Over & $16 / 05 / 2017$ & $17 / 05 / 2017$ & 2 \\
\hline 20 & Demobilization 1 & $17 / 05 / 2017$ & $18 / 05 / 2017$ & 2 \\
\hline 21 & Installation Of Platform W8t & $18 / 05 / 2017$ & $19 / 05 / 2017$ & 2 \\
\hline 22 & Installation Of Platform W2t & $20 / 05 / 2017$ & $21 / 05 / 2017$ & 2 \\
\hline 23 & Painting Of Well Head W8t & $20 / 05 / 2017$ & $21 / 05 / 2017$ & 2 \\
\hline 24 & Painting Of Well Head W2t & $21 / 05 / 2017$ & $22 / 05 / 2017$ & 2 \\
\hline 25 & Site Restoration & $22 / 05 / 2017$ & $23 / 05 / 2017$ & 2 \\
\hline 26 & Demobilization 2 & $23 / 05 / 2017$ & $24 / 05 / 2017$ & 2 \\
\hline 27 & Close Out Report & $26 / 05 / 2017$ & $31 / 05 / 2017$ & 6 \\
\hline
\end{tabular}


APPENDIX C: PERT FOR APPENDIX A (DETERMINISTIC DURATION, EXPECTED MEAN TIME, VARIANCE AND STANDARD DEVIATION)

\begin{tabular}{|c|c|c|c|c|c|c|c|c|c|c|}
\hline Activity & $\begin{array}{l}\text { Optimistic } \\
\text { (A) }\end{array}$ & $\begin{array}{l}\text { Pessimistic } \\
\text { (B) }\end{array}$ & $\begin{array}{l}\text { Most Likely } \\
\text { (M) }\end{array}$ & $4 m$ & $\begin{array}{l}C= \\
(A+4 m+B)\end{array}$ & $\mathrm{C} / 6$ & $\mathbf{D}=(\mathbf{B}-\mathbf{A})$ & $D / 6$ & $(\mathrm{D} / 6)^{2}$ & $\mathrm{Cpm}$ \\
\hline Mobilization & 2 & 7 & 3 & 12 & 22 & 3.500 & 5.000 & 0.833 & 0.694 & $\mathrm{CPM}$ \\
\hline $\begin{array}{l}\text { Hse Induction And } \\
\text { Certification }\end{array}$ & 2 & 5 & 3 & 12 & 20 & 3.167 & 3.000 & 0.500 & 0.250 & $\mathrm{CPM}$ \\
\hline Survey And Mapping Out & 3 & 5 & 4 & 16 & 25 & 4.000 & 2.000 & 0.333 & 0.111 & $\mathrm{CPM}$ \\
\hline $\begin{array}{l}\text { Bush Clearing And } \\
\text { Excavation }\end{array}$ & 4 & 7 & 5 & 20 & 32 & 5.167 & 3.000 & 0.500 & 0.250 & $\mathrm{CPM}$ \\
\hline Site Preparation & 1 & 3 & 2 & 8 & 13 & 2.000 & 2.000 & 0.333 & 0.111 & \\
\hline Lay And Weld & 16 & 24 & 20 & 80 & 124 & 20.000 & 8.000 & 1.333 & 1.778 & CPM \\
\hline Ndt And Coating & 16 & 24 & 20 & 80 & 124 & 20.000 & 8.000 & 1.333 & 1.778 & \\
\hline River Crossing & 2 & 5 & 3 & 12 & 20 & 3.167 & 3.000 & 0.500 & 0.250 & $\mathrm{CPM}$ \\
\hline Pipe Alignment & 2 & 9 & 6 & 24 & 39 & 5.833 & 7.000 & 1.167 & 1.361 & $\mathrm{CPM}$ \\
\hline Tie In & 8 & 13 & 9 & 36 & 58 & 9.500 & 5.000 & 0.833 & 0.694 & $\mathrm{CPM}$ \\
\hline Flushing And Pipe Filling & 1 & 1 & 1 & 4 & 6 & 1.000 & 0.000 & 0.000 & 0.000 & CPM \\
\hline Pressure Testing & 3 & 9 & 4 & 16 & 29 & 4.667 & 6.000 & 1.000 & 1.000 & $\mathrm{CPM}$ \\
\hline Hook Up & 1 & 1 & 1 & 4 & 6 & 1.000 & 0.000 & 0.000 & 0.000 & \\
\hline Back Filling & 3 & 5 & 3 & 12 & 20 & 3.333 & 2.000 & 0.333 & 0.111 & $\mathrm{CPM}$ \\
\hline $\begin{array}{l}\text { Commissioning And Hand } \\
\text { Over }\end{array}$ & 2 & 4 & 3 & 12 & 19 & 3.000 & 2.000 & 0.333 & 0.111 & $\mathrm{CPM}$ \\
\hline Site Restoration & 2 & 3 & 1 & 4 & 8 & 1.500 & 1.000 & 0.167 & 0.028 & CPM \\
\hline Demobilization & 3 & 5 & 2 & 8 & 15 & 2.667 & 2.000 & 0.333 & 0.111 & $\mathrm{CPM}$ \\
\hline \multirow[t]{2}{*}{ Close Out Report } & 7 & 13 & 8 & 32 & 53 & 8.667 & 6.000 & 1.000 & 1.000 & CPM \\
\hline & 60.000 & & & & & 79.167 & 55.000 & 9.167 & 7.750 & 2.784 \\
\hline
\end{tabular}

APPENDIX D: PROBABILITY OF COMPLETING THE JOB A DAY AFTER EXPECTED MEAN TIME E

\begin{tabular}{|c|c|c|c|c|c|c|c|c|}
\hline $\mathbf{S} / \mathbf{N}$ & Appendix & $\overline{~ C P M ~(E) ~}$ & $\bar{\partial}$ & $\overline{\mathbf{X}}$ & $\bar{E}+\mathbf{X}$ & PERT & $\overline{Z Z}$ & $\overline{\%} \% \mathrm{Z}_{\mathrm{E}+1}$ \\
\hline 1 & Appendix G & 79 & 2.784 & 1 & 80 & 0.359 & 0.640 & $64 \%$ \\
\hline 2 & Appendix $\mathrm{H}$ & 52 & 1.848 & 1 & 53 & 0.541 & 0.706 & $71 \%$ \\
\hline 3 & Appendix I & 67 & 2.577 & 1 & 68 & 0.388 & 0.651 & $65 \%$ \\
\hline 4 & Appendix $\mathrm{J}$ & 70 & 1.803 & 1 & 71 & 0.555 & 0.710 & $71 \%$ \\
\hline 5 & Appendix $\mathrm{K}$ & 74 & 2.034 & 1 & 75 & 0.492 & 0.689 & $69 \%$ \\
\hline 6 & Appendix M & 66 & 2.297 & 1 & 67 & 0.435 & 0.668 & $67 \%$ \\
\hline
\end{tabular}

\begin{tabular}{|c|c|c|c|c|c|c|c|c|}
\hline \multirow[b]{2}{*}{$\mathbf{S} / \mathbf{N}$} & \multicolumn{8}{|c|}{ Probability of completıng the project 4 days before expected mean time } \\
\hline & Appendix & CPM (E) & $\partial$ & X4 & E-X & PERT & $\mathbf{Z}$ & $\% \mathbf{Z}_{\mathrm{E}-4}$ \\
\hline 1 & Appendix G & 79 & 2.784 & 4 & 75 & -1.437 & 0.075 & $8 \%$ \\
\hline 2 & Appendix $\mathrm{H}$ & 52 & 1.848 & 4 & 48 & -2.165 & 0.015 & $2 \%$ \\
\hline 3 & Appendix I & 67 & 2.577 & 4 & 63 & -1.552 & 0.060 & $6 \%$ \\
\hline 4 & Appendix J & 70 & 1.803 & 4 & 66 & -2.219 & 0.013 & $1 \%$ \\
\hline 5 & Appendix $\mathrm{K}$ & 74 & 2.034 & 4 & 70 & -1.967 & 0.025 & $2 \%$ \\
\hline 6 & Appendix $\mathrm{M}$ & 66 & 2.297 & 4 & 62 & -1.741 & 0.041 & $4 \%$ \\
\hline
\end{tabular}

Probability of completion between expected mean time $\mathrm{E}$ and 4 days before $\mathrm{E}$

$\begin{array}{llll}\mathbf{S} / \mathbf{N} & \mathbf{Z 2} & \mathbf{Z 1} & \begin{array}{r}\text { Probability Of Co } \\ 1\end{array} \\ 2 & 64 & 8 & \mathbf{Z 2 - Z 1} \\ 2 & 71 & 2 & 56 \\ 3 & 65 & 6 & 69 \\ 4 & 71 & 1 & 59 \\ 5 & 69 & 2 & 70 \\ 6 & 67 & 4 & 67 \\ & & & 63\end{array}$

Probability of completing the project using deterministic Variable

\begin{tabular}{|c|c|c|c|c|c|c|c|}
\hline $\mathbf{S} / \mathbf{N}$ & TABLES & CPM (E) & $\partial$ & $\mathbf{X E}$ & PERT & $\mathbf{Z}$ & $\% \mathbf{Z 2}$ \\
\hline 1 & Table I & 60 & 2.784 & 60 & 0 & 0.5 & $50 \%$ \\
\hline 2 & Table II & 39 & 1.848 & 39 & 0 & 0.5 & $50 \%$ \\
\hline 3 & Table III & 49 & 2.297 & 49 & 0 & 0.5 & $50 \%$ \\
\hline 5 & Table V & 41 & 2.034 & 41 & 0 & 0.5 & $50 \%$ \\
\hline 6 & Table VI & 51 & 2.297 & 51 & 0 & 0.5 & $50 \%$ \\
\hline
\end{tabular}

\section{REFERENCES}

[1] Daketima, G. Briggs (2017). Comparison between Deterministic and Stochastic Time Estimating Techniques. International Journal of Advanced Research in Science, Engineering and Technology. 4(7) July 2017, Retrieved from www.ijaret.com, on $10^{\text {th }}$ October 2018.
[2] Everett, E. A., \& Ronald, J. E. (2013). Production and Operations Management, Concept, models and behaviour. (5 $5^{\text {th }}$ ed.) Asoke $\mathrm{K}$ Chosh PHI (learning private ltd.)

[3] François, B. (2015): Five causes of project delay and cost overrun.www.linkein.com/François-buys Retrieved on $05^{\text {th }}$ April 2017.

[4] Gabriel, B. (2016). Unexpected event in the Nigeria construction project. A case study of four companies. Walden University. PHD 
Thesis. Retrieved from https:scholarworks.waldenu.edu/dissertation $05^{\text {th }}$ Aprill 2017

[5] Iulian, T (2004). Impact of uncertainty on construction project performance using linear scheduling, University of Florida.

[6] Khan, S (2015). An analysis on critical causes of delays in oil and gas construction projects. Project Management National Conference September 10-12, 2015/ A PMI Team event. The Lalit Ashok Bengaluru, India.

[7] Roseke, B. (2014). QSM Quality management system. Retrieved (26 July 2017) from www.roseke.com

[8] Martand, T (2012). Industrial Engineering and Production Management. ( $2^{\text {nd }}$ ed.). S. CHAND and company ltd.
[9] Ograbe, A. J., Ahiakwo. O., OLoke, D. Subashini, S. \& Khatib, J. (2015). Implementing the last planner system in a road construction project in Nigeria. Built Environment journal of Faculty of Architecture, planning and surveying 12 (2)

[10] Rama. S, Sathya A, Shasikala A, \& Cilfa. Irene (2017). A study on Project Planning Using the Deterministic and Probability Models by Network Scheduling Techniques. Rama. S et al. Int Journal of Engineering Research and Application. ISSN: 2248-9622, 7(3), (Part -4), pp.32-38.

[11] Sharma, J.K. (2013). (5 $5^{\text {th }}$ ed.) Operations Research. Theory and Applications. Trinity press, an imprint of Laximi Publications Pvt ltd, Macmillan publishers India. 